\title{
Involving microfinance industry in financial inclusion through social incubators
}

\author{
[Sara LEBBAR, Pr. Mustapha CHAMI]
}

\begin{abstract}
Microfinance industry is a key sector in supporting inclusive development. However, this sector suffers from high costs worldwide. Very few studies focused on decreasing microfinance cost and support processes of needy entrepreneurs [1] to whom are assimilated the majority of microcredit holders. This work aims to assess Microfinance institutions' (MFI's) performance and to analyze their cost structure. The innovative idea is to provide a financial offer in adequacy to these institutions' and to microcredit beneficiaries' needs through a network structure. It emerges from the analysis that, the cost of microfinance is high and consists mainly of operating expenses. MFI's apply high interest rates in order to cover their expenses and compensate their losses. Microcredit beneficiaries, over-indebted, cannot pay-off their debts. This fact leads to reducing of the long term profitability of these institutions. A network structure through non-profit incubators might reduce of microfinance institutions' transaction costs and encourage them to provide a favorable offer to a sustainable inclusive growth.
\end{abstract}

Keywords-Microfinance, Microcredit, Cost, Networks, Incubator

\section{Introduction}

During the last decades, a special attention had been given to inclusive growth as a tool to promote equity [2]. We can define the inclusive growth concept considering the increasing wealth produced in a country, matching mechanisms of redistribution that can reach the majority of the population [3]. This is accompanied by a reduction in income disparities [4] and focuses on productive employment. The employment growth increases incomes. Job creation remains a major challenge to make growth truly inclusive [3].

Six hundred million additional jobs must be created worldwide by 2030 to stabilize employment levels [5]. Job creation remains dependent on the access of small enterprises and medium enterprises to financing because they are the origin of four new jobs over five [5]. Because of the lack of bank guarantees, those enterprises cannot be financed therefore microfinance is important.

Professor Mohammad Yunus, holder of the Nobel Peace Prize in 2006 and founder of Grameen Bank or "village bank" in Bangladesh was inspired by the tontine logic and allowed to lend to customers who have no collateral to take

Sara LEBBAR

National School of Business and Management/ Hassan $1^{\text {st }}$ University Morocco

Mustapha CHAMI

National School of Business and Management/ Hassan $1^{\text {st }}$ University Morocco them out off a precarious financial situation. The repayment rate reached in the early 1990s, 95 to $97 \%$ [6]. Microfinance has proved that the poor are bankable [7]. Nevertheless, the sector is suffering from increasingly numerous challenges that go against its social purpose.

The problem of high interest rates of microcredit is the subject of many debates since the early modern history of microfinance in the late 1970s. Multiple writings raise the negative effect of debt on the cross microcredit beneficiaries [8]. While some claim a legal ceiling on interest rates, others criticize the transformation of an increasing number of MFIs in private trading companies.

MFIs' interest rates include four essential elements: the cost of resources, provisions for doubtful accounts, operating expenses and earnings [9]. Operating expenses represent the highest cost component [9]. Reduction of charges involves access to competitive resources. In theory, entrepreneurs' access to resources can be operated mainly through social networks with the incubator as an intermediary. Besides, the incubators have become, in recent years, a way for public policies to promote economic development and innovation [10].

We ask the question: How can we reduce the cost of microfinance through a university incubation system with a social purpose?

We propose to introduce the social network theory [11] combined with the concept of social capital [12] to try to understand the mechanisms of transaction cost reduction [13] through microfinance institutions. The first part would compile a literature review that would include three sections. These deal respectively microfinance concepts, incubation and key elements of the theories mobilized to reinforce our thinking. The second part describes the methodology used. Preliminary results will be disclosed in a third part to finally lead to a discussion in a fourth front, to, then, conclude and present the perspectives of our research.

\section{Microfinance worldwide}

\section{A. Definitions and Overall Balance}

Microfinance consists on financial inclusion. There is a wide range of financial services available to marginalized people who are excluded from the traditional banking system. Microfinance offer includes group loans, individual loans, guarantee funds, venture capital, savings, insurance of property and persons, transfers for migrants as well as the support services. 
MFIs have a double economic and social objective. They may operate under the legal form of cooperative, mutual association, commercial bank or non-governmental organization. They get their financing from investment funds, debt, refinancing and subsidies.

Middle East and North Africa count for $23 \%$ of gross loan portfolio, respectively followed by Latin America and South Asia with $23 \%$ and $20 \%$ [14]. We distinguish the Grameen Bank in Bangladesh, Bank Rakyat Indonesia, Bolivia Bancosol or CERUDEB Uganda.

\section{B. Microfinance institutions, financial autonomy}

Two main currents discuss the issue of financial autonomy of MFIs. While the institutional approach advocates the pursuit of profit for the financial sustainability of MFIs, the welfarist approach promotes social welfare. The opposition between these two visions is described by [15] as the schism of microfinance. These two approaches provide a different view of what should be the priorities and function of microfinance institutions. According to [16] the pursuit of financial efficiency is considered is followed by sustainable social efficiency of microfinance institutions.

The risk of commercialization of MFIs due to the high interest rates applied forced the repayment capacity of the microcredit's beneficiaries. Moreover, the high cost of microfinance supported by these institutions threatens the social sector issues. The linkage between the economic and the social could be operated through the intermediation concept of a third party [17] who will intervene to support MFIs and their clients to reduce the cost of the sector.

\section{The problem of high interest rates and credit rationing theory}

Microfinance industry is characterized by an asymmetry of information raised by Stiglitz and Weiss [18] through the modern theory of finance. The borrower has accurate information about his solvency, the risk level of the project he has undertaken and the potential returns level of the project. The lender, meanwhile, does not have the same information. This asymmetry of information between lenders and borrowers leads to a rationed balance. Adverse selection and moral hazard phenomena cannot lead to equilibrium through interest rate changes. The lender, can no more adapt the price level, so he varies the quantities and limits, rationally, the amount of credit granted.

Thus, according to the credit rationing theory, increasing interest rates above a certain threshold would lead to diminishing returns. Holders of less risky projects may not generate returns allowing them to pay high interest rates and are therefore excluded from the market. The average risk of the banks' credit portfolio will increase, as composed largely of high-risky projects, which would decrease the expected bank return. Therefore, credit rationing limits the amount of credit distributed, reduces client portfolio at risk and maximize profitability but would leave unsatisfied demand. MFIs should therefore maximize their resources to offset their losses.

\section{Involving incubators through financial inclusion}

Business incubators are structures that enable the creation, development and maintenance of enterprises during their first years [19]. They diversify and stabilize resources, knowledge and skills of the new entrepreneur to cope with various shocks and crises encountered [20]. They offer a wide range of services, such as physical space, capital, coaches, common services.

Incubators emerged in the US at the $50 \mathrm{~s}$ before experiencing strong growth in other countries from the 70s. In China, business incubators appeared in 1987 and were specialized in the technological industries (Information technologies, pharmaceuticals ...).

Incubators support local economic development, particularly, by encouraging job creation and supporting projects that combine economic dimension and social dimension [21]. The current research on incubators is young and turned much more towards description and exploration rather than explanation [22].

\section{A. Incubators support to entrepreneurs by necessity}

Exploring microfinance institutions' and micro entrepreneurs' accompaniment sparked our interest. Indeed, microcredit carriers can be assimilated to necessity entrepreneurs. The entrepreneur by necessity refers to anyone who decides to get involved in entrepreneurial activity as he has no alternative to finding a job. This is linked to "push" factors such as dismissal, unemployment or threat of losing a job [23]. Very few studies dealt with accompanying necessity entrepreneurs [1]. Customize and adapt devices thereon remains significant.

Moreover, business incubators may handle commercial or social mission, public or private. As we follow a social objective, we prioritized the action of a public non-profit incubator, also named, university or academic incubator.

\section{B. Academic incubators}

Many economists and policymakers agree that the diffusion of innovations does not follow a linear path but an interactive process network [24].

The University-Firm-State triad creates systemic networks of interactive spirals [25] that allow the expansion of the knowledge role in society and the university in the economy. Thus, university takes the role of industry when it contributes to the creation of spin-off companies in its incubator. The state takes the role of industry in supporting its growth through financing and regulatory measures and programs. Industry can take the role of the university when 
enhancing research and training [26]. The main consequence of this interchangeability of roles is the emergence of networks with these three players combined actions.

Plenty of technological innovations have been carried for decades such as Google, Cisco, Microsoft born from research conducted in Silicon Valley in California, but what about the social aspect? The study of the potential implementation of a public incubation device socially oriented within universities is part of "social innovation".

Academic and scientific incubators are efficient catalysts that allow better use of existing resources and projects [22]. They can function effectively only if they are deeply supported by the scientific, industrial and local financial community so as to be introduced into the relevant business networks for start-up creation [22].

\section{Developping networks}

The Relying on a triadic vision of relations, Tähtinen [27], for example, showed the importance of intermediaries in the structure and dynamics of networks. In a network structure, intermediaries are required for trades [28]. Inserting incubators in social and professional networks ensures trust and facilitates access to resources [29].

This design is part of the Resources Based View (RBV) considering that a company is sustainable and innovative when it controls when relevant, rare and hardly transferable resources. Bringing resources and skills via incubators increases the chances of small businesses survival and accelerates their growth [30]. Incubators are now located at the interface of several sources of information, and bridge structural holes [12] between micro entrepreneurs and external partners.

We tried to understand this intermediation phenomenon taking place at the interaction between actors and explored it through the social network theory oriented towards RBV approach, the theory of social capital [31]; [29]; [12] and the theory of transaction costs [13].

\section{Iv. The theoretical famework}

After the text edit has been completed, the paper is ready for the template. Duplicate the template file by using the Save As command, and use the naming convention prescribed by your conference for the name of your paper. In this newly created file, highlight all of the contents and import your prepared text file. You are now ready to style your paper; use the scroll down window on the left of the MS Word Formatting toolbar.

\section{A. Transaction Cost Theory}

We relied on this theory because it is a theory of contracts and organizations between economic agents providing a mutual interest in cooperating.

Coase (1937) was the first to raise the issue of the transaction costs theory. He says the access to the market has a cost. Williamson (1985) includes the work of Coase suggesting a reconstruction of the economic theory of the firm based on the costs that economic agents support to ensure exchange on the market. He defines transaction costs as all specifically costs related to managing the confrontation between two economic agents integrating contract preparation costs, monitoring, implementation and control. He makes two basic assumptions: agents' bounded rationality and agents' opportunism. In the first case, individuals cannot predict in advance all eventualities. The contracts they will conclude are necessarily incomplete because they cannot define in advance all the obligations of partners for the different possible states of the world. This causes transaction costs (editing, management, renegotiation of contracts). In the second case, individuals exhibit opportunistic behavior by seeking personal interests and resorting to deception, guile or concealment.

The nature of transactions is determined by three criteria:

- Assets specificity: when a sustainable investment has to be made to support a particular transaction without having the possibility to redeploy it on another transaction. Indeed, MFIs' staff treats each request differently depending on the customer's needs. Consequently, assets are specific to one transaction which is neither anonymous nor instantaneous, and there is a durable length between the borrower and the MFI.

- Exchange uncertainty: it refers to the impossibility of predicting the future, hazards, and coming behaviors of the borrower. The uncertainty analysis in microfinance was inspired from the banking theory, highlighting the contractual innovations in reducing asymmetry information effects through group lending [32].

- Exchange frequency: The more the frequency is raised, the more the risk of opportunism is brought up and the more the mobilization of resources to minimize transaction costs is justified. The IMF seeks to increase its loan portfolio.

Agents' bounded rationality and opportunism increase transaction costs. This raises the question of integration or outsourcing of certain activities of the firm and the choice of the type of institutional arrangement that minimizes transaction costs. The author distinguishes among other bilateral governance where the assets are specific and where transactions are recurrent. The relationship takes the form of an organization in the context of "hybrid" structures, intermediaries between the firm and the market such as alliances, partnerships, joint ventures, subcontractors networks, network franchises, etc ... We talk also about strategic networks [33]. In such a configuration, the MFI will rather outsource certain functions to reduce its cost. This brings us to the second theory adopted, namely social networks. 


\section{B. Social Network Theory}

A social network corresponds to the nodes that form a set of actors, groups and / or organizations [11]. Several studies [34] show that resources expected from a supporting network must provide the accompanied access to partners, funding, training, premises, equipment and materials needed to provide competitive advantages.

The creation of a company is not only based on traditional pillars such as labor, capital and technology, but also, on social goods usually called social capital [35]. The social capital may be considered as a public asset or an individual attribute. In the first case, it is the relationships within a group or groups that make up the social capital, in addition to cultural determining factors which are standards, trust and reciprocity actions [29]. In the second case, social networks become social capital if they can mobilize external resources through intermediaries [28]. The incubator is thus presented as the intermediary allowing actors of the two groups to meet and to establish mutually beneficial relationships. The incubator can create and develop different resources, services and skills [36]. The most important aspect of incubation is the creation of networks that allow the expansion of a variety of services and support to startups [21].

\section{Reducing transaction costs using a network structure}

The work of White (1981) and Granovetter (1985) found that belonging to a network is a source of competitive advantage, as it helps to reduce transaction costs between network members and increase their ability to mobilize resources. When transactions are difficult to clarify in contracting, the social network can avoid opportunistic behavior and reduce transaction costs [37].

According to Bourdieu (1980), the fact of belonging to networks, to a structure or organization, can facilitate obtaining a job, access to non-commercial resources or market resources but at a lower cost. The role of networks in the development of relations between the actors is confirmed, it still remains how this networking could be established.

\section{Acknowledgment}

The transformation of the relationship between Science and Society characterize the end of the differentiation between the two fields. Our goal is not to create new theories but rather to enrich the research on the fight against poverty. We fit well in an epistemological framework of moderate constructivism as we want to build a reality; we aim to reduce the cost of microfinance through a network structure with academic incubators as intermediaries.

A qualitative approach would lead us to make an exploratory research to identify the degree of cooperation between universities, microfinance institutions and borrowers.
An abductive method for an innovative theoretical exploration would lead us to make a connection between two disciplines which were not theoretically related previously. Firslty, microfinance whose aim is above all social, secondly, social innovation through university incubation. The exploration is essential to our project to understand a subject that remains poorly studied, namely the incubation process of MFIs, the nature of the resources mobilized and the interpretation of the actors involved in this process.

\section{References}

[1] Bosma, N. and Levie, J. (2009), Global Entrepreneurship Monitor: 2009 Global Report. Available at : http://www.gemconsortium.org/ [Accessed August 21, 2010].

Couteret, P. (2010), Peut-on aider les entrepreneurs contraints? Une étude exploratoire, Revue de l'Entrepreneuriat, Vol. 9, $\mathrm{n}^{\circ} 2$.

[2] Ali, I. (2007a), Pro-Poor to Inclusive Growth: Asian Prescriptions, ERD Policy Brief, $\mathrm{n}^{\circ}$ 48, mai ; Manille, Banque asiatique de développement.

Ali, I. (2007b), Inequality and the Imperative for Inclusive Growth, Asian Development Review, Vol. 24, n², p. 1-16.

Felipe, J. (2010), Inclusive Growth, Full Employment, and Structural Change: Implications and Policies for Developing Asia, $A D B$ and Anthem Press, Londres.

Klasen, S. (2010), Measuring and Monitoring Inclusive Growth: Multiple Definitions, Open Questions, and Some Constructive Proposals, ADB Sustainable Development Working Paper Series, $\mathrm{n}^{\circ} 12$, juin.

Tandon, A. and Juzhong, Z. (2007), Inclusiveness of Economic Growth in the People's Republic of China: What Do Population Health Outcomes Tell Us?, ERD Policy Brief, $\mathrm{n}^{\circ}$ 47, Manille, Banque Asiatique de Développement.

[3] BAD, (2013), La recherche d'une croissance inclusive en Afrique du Nord : une approche comparative. Note Economique.

[4] Rauniyar, G. and Kanbur, R. (2010), Inclusive Development: Two Papers on Conceptualization, Application, and the ADB Perspective, Projet de janvier; Département des évaluations indépendantes, Manille, Banque Asiatique de Développement.

[5] World Bank Group, (2014), The Global Findex Database 2014. Measuring Financial Inclusion around the World, Policy research working paper, $\mathrm{n}^{\circ} 7255$, April 2015.

[6] Grameen, (2001), Grameen Fund Financial Performance. Available at http://www.grameeninfo.org/grameen/gfund/index.html

[7] Banerjee. A.V., Duflo, E., Glennerster, R. and Kinnan, C. (2010), The Miracle of Microfinance? Evidence from a Randomized Evaluation, Cambridge, Mass.: J-PAL et MIT, juin 2010.

[8] Bateman, M. (2010), Why Microfinance deosn't Work? The Destructive Rise of Local Neo-Liberalism, Zed Books, Ltd., London, U.K.

Sinclair, H. (2012), Confessions of a Microfinance Heretic. How Microfinance Lost its Way and Betrayed the Poor, Berret-Koehler Publishers, Inc., San Francisco, CA. 
Ashta, A. (2013), Contextualising microfinance research. Journal of Innovation Economics \& Management, 2013/1 $\mathrm{n}^{\circ} 11 \mid \mathrm{p} 3-14$.

[9] CGAP. (2013), Les taux d'intérêt du microcrédit et leurs facteurs déterminants 2004-2011. Rapports du CGAP et de ses partenaires, $\mathrm{N}^{\circ} 7$, Juin 2013.

[10] Bergek, A. and Norrman, C. (2008), Incubator best pratice: A Framework, Technovation, vol. 28, $\mathrm{n}^{\circ}$ 1-2, janvier-février 2008, p 20-28.

Akçomak, S., Incubators as Tools for Entrepreneurship Promotion in Developing Countries, Working Paper UNUMERIT 2009-054, 2009.

[11] White, H.C. (1981), Where do market come from?, American journal of sociology, Vol. 87, n`3, p. 517-547.

Granovetter, M. (1985), Economic action and social structure: the problem of embeddedness, American Journal of Sociology, Vol. 91, n³, p. 481-510.

[12] Burt, R. (2000), The network structure of social capital, in R.I. Sutton et B.M. Staw, Research in Organizational Behavior, vol. 22, JAI Press, p. 345-423.

Flap, H. (2002), No man is an island: the research programme of social capital theory, in: O.Favereau and E. Lazega (eds.), Conventions and structures. Markets, networks and hierarchies, Cheltenham: Edward Elgar, p. 2959.

Lin, and al. (1981), Social Resources and Occupational Status Attainment, Social Forces, Vol. 59, №4 : 1163-1181.

[13] Williamson, O.E. (1979), Transaction-cost economics: The governance of contractual relations, Journal of Law and Economics, Vol. 22, Octobre 1979, p. 3-61.

Williamson, O.E., The Economic Institutions of Capitalism, Free Press, New York, 1985.

Williamson, O.E. (1998), Transaction Cost Economics: How It Works; Where it is Going, De Economist, Vol. 146, Avril 1998, p. 23-58.

[14] Microrate Incorporated, Guide Technique. Indicateurs sociaux et indicateurs de performance pour les institutions de microfinance, 2014

[15] Morduch, J. (2000), The Microfinance Shism, World Development, Vol. $28, \mathrm{n}^{\circ} 4$

[16] Mersland, R. and Strøm R. Ø. (2010), Microfinance mission drift?, World Development, vol. $38, \mathrm{n}^{\circ} 1$, January 2010, p. 28-36

[17] Servet, J.M, Banquiers aux pieds nus, Ed. Odile Jacob, 2006, 511 p.p. 461-462

[18] Stiglitz, J. and Weiss, A. (1981), Credit rationing in markets with imperfect information. American

Economic Review, Vol. 71, n³, p. 393-419.

[19] Grimaldi. R. and Grandi, A. (2005), Business incubators and new venture creation: an assessment of incubating models, Technovation, 25 (2005) p 111-121.

[20] Vohora, A. and al. (2004), Critical junctures in the development of university high-tech spin-out companies, Research Policy, Vol. 33, p. 147-175.

[21] Aernoudt, R. (2004), Incubators: tool for entrepreneurship?, Small Business Economics, Vol. 23, No. 2, pp.127-135.

[22] Albert, P., Bernasconi, M., Gaynor, G., (2003), Incubateurs et pépinière d'entreprises : un panorama international, L'harmattan, Paris.

[23] Thurik, A.R., Carree, M.A., Van Stel, A.J. and Audretsch, D.B. (2008), Does self-employment reduce unemployment?, Journal of Business Venturing, Vol. 23, No. 6, p. 673-686.

[24] Etzkowitz, $H$. and al. (2000), The Future of the University and the University of the Future : Evolution from Ivory Tower to Entrepreneurial Paradigm », Research Policy, vol. 29, p. 313-330.

Rothwell, R. (2002), Toward the fifth-generation innovation process, In J.H. and D. Mayle (eds.), Managing innovation and change, London: Sage Publications, p. 115-135.

[25] Etzkowitz H. and Leydesdorff L. (2000), The dynamics of innovation: from National systems and "mode 2" to a triple Helix of university-industry-government relations, Research Policy, 29: 109-123.

[26] Etzkowitz, H. (2001), The second academic revolution and the rise of entrepreneurial state. IEEE Technology and Society, Vol. 22, n², p. 18-29.

[27] Tähtinen, J. (2002), Triad net dissolution, Proceedings of EMAC-ANZMAC Colloquium, 16-17 December, Perth, Australia.

[28] Degenne, A. and Forsé, M. (2004), Les réseaux sociaux, Paris: Armand Colin.

[29] Coleman, J. (1988), Social capital and the creation of human capital, American Journal of Sociology, 94: S95S120

[30] Frenkel, A., Shefer, D., Miller, M. (2008), Public versus Private Technological Incubator Programs : Privatizing the Technological Incubators in Israel, European Planning Studies, Vol. 16, No 2, p.189-210.

[31] Granovetter, M. (1973), The strength of weak ties, American Journal of Sociology, Vol. 78:1360- 1380.

Bourdieu, P. (1980), Le capital social. Notes provisoires, Acte de la Recherche en Science Sociales, Vol. 31, p. 2-3.

[32] Stiglitz, J. (1990), Peer Monitoring and Credit Markets, World Bank Econ. Rev, Vol. 4, n³, p.351-66.

[33] Gulati, and al. (2000), Strategic networks, Strategic Management Journal, Vol. 21, p. 203-215.

[34] Grossetti, M. and Barthe, J-F. (2010), Dynamique des réseaux interpersonnels et des organisations dans les créations d'entreprises ", Revue française de sociologie, 493, 208, p.585-612.

[35] Bögenhold, D. (2002), Social capital as strategic element of venture creation, 2nd Annual conference of the European Academy of Management, Stockholm, May 9-11 [36] Bollingtoft, A. and Ulhoi, J.P. (2005), The networked business incubator - leveraging entrepreneurial agency?, Journal of Business Venturing, vol. 20, n 2, p. 265-290.

Chandra, P. and al. (2003), Innovation, incubation, and incubator, Vikalpa, Vol. 28, n², p. 89-94.

[37] Baret, C. and al. (2006), Management et réseaux sociaux. Jeux d'ombres et de lumières sur les organisations, Revue Française de Gestion, Vol. 32, n 163, p. 93-106.

About Author (s):

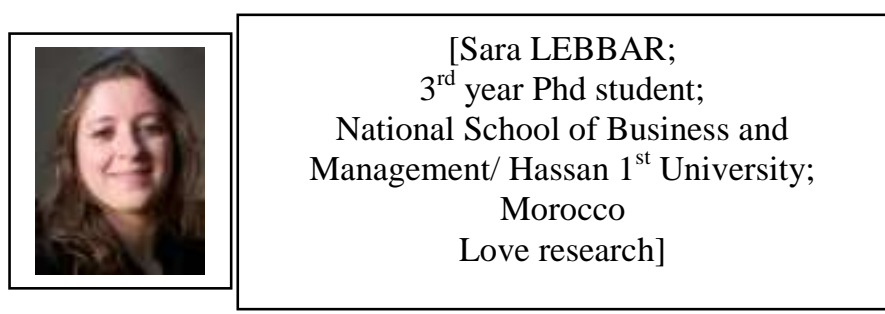

